\title{
Strategic Orientation and Effects of E-Administration: Findings from the Miles and Snow Framework
}

\author{
Liliana Hawrysz \\ Department of Process Management, Faculty of Management Warsaw University of Technology, \\ 00-661 Warszawa, Poland; liliana.hawrysz@pw.edu.pl
}

Received: 7 May 2020; Accepted: 15 June 2020; Published: 18 June 2020

check for updates

\begin{abstract}
Much has been written about the strategic orientation of public administration organizations (prospecting, defending, reacting, and analyzing) and their consequences for organizational effects, but little is dedicated to e-administration. Is the provision of services using IT affecting the adoption of strategic orientation and its effects? The paper is dealing with e-administration issues, specifically in terms of the impact of the Miles and Snow strategic orientation on e-administration effects. To measure e-administration effects, the author's personal tool using the Common Assessment Framework (CAF) criterion has been proposed. The data collection was conducted using the Computer-Assisted Web Interview (CAWI) method, in the period from November 2017 to January 2018. Two hundred and twenty-six Polish organizations took part in the study. The objective of this study, i.e., assessing the impact of strategic orientation and e-administration effects, was achieved by using the Ordinary Least Squares (OLS) method. It is indicated that the Defender orientation is positively associated with the effects of e-administration.
\end{abstract}

Keywords: strategic orientation; effects; e-administration; Miles and Snow framework

\section{Introduction}

Strategic management has become more important in public administration because of the increased emphasis that was placed on attaining higher levels of performance (Poister et al. 2010; Walker 2013). A focus on goals, planning, and innovation underlies reforms related to New Public Management, while the citizens' expectations for public services are still rising, thereby requiring more strategic responses to meet these needs (Harrow 2000; Walker et al. 2013).

The correct strategy design requires familiarity with the sector's specificity, because an organization's strategy must be embedded in a particular context of its environment, thereby determining the key assumptions adopted for the strategy's design and for planned activities' implementation (Wronka-Pośpiech and Frączkiewicz-Wronka 2016). Designing the strategy for the effective functioning of e-administration requires the involvement of the general populace, creating and strengthening the role of public administration staff, procedural and organizational changes/improvements, as well as transforming and adapting the legal background to new circumstances. All organizations, especially those effectively using IT, require a strategic approach and necessitate the creation of short-, medium-, and long-term strategies. However, due to the unpredictability and continuous evolution of this field and the IT involved, these strategies must be flexible, adaptable, and always ready for renewal. As increasing numbers of public services become digital by default, the efficiency of public spending on IT solutions should be maximized by sharing and recycling known solutions (Nograšek and Vintar 2015). The research on strategy can be broadly divided into two categories: one that prioritizes the analysis of the external environment (as in the Porter's model) and the other, taking greater consideration of the internal environment (as in the Resource Based View model). The adaptive cycle process of Miles and Snow is in the middle of these issues (Miles et al. 1978). 
Some researchers claim that the general framework offered by Miles and Snow is appropriate with some adaptations to public organizations (Boyne and Walker 2004). Miles and Snow argue that the organization's success depends on the external (environment) and internal (strategy, structure, processes, and ideology) process (Miles et al. 1978). They propose four strategic orientations-prospecting, defending, reacting and analyzing (Meier et al. 2010). This paper takes into consideration the framework offered by Miles and Snow to indicate the strategic orientation of e-administration. The indicated strategic orientations were paired with e-administration effects. To measure e-administration effects, the author's personal tool using the Common Assessment Framework (CAF) criterion has been proposed.

Based on the literature, it is frequently claimed that the availability of an assessment framework is a necessary condition for advancing e-administration proper implementation. Most e-administration appraisal models address the e-service dimension of e-administration that focuses on the services provided by the government to the citizens on the Internet. This gives a very narrow perspective to e-administration while ignoring a key dimension — the e-administration, that highlights the importance of modernizing the public administration, increasing administration productivity, and transforming its internal processes. The majority of these models do not take into consideration the opinion of the civil servants involved in such e-government programs, a key stakeholder that affects their success. That is why in our research we use the CAF model. The CAF model enables self-assessment by public administration units, and also serves as a tool to support international cooperation and exchange of experience. It is also a starting point for measuring and conducting comparisons between public administration organizations. The model primarily focuses on assessing management, performance, and identifying its organizational evidence. Therefore, it is to contribute to the flexible response to the changing needs of citizens (Vakalopoulou et al. 2013).

This paper was mainly focused on providing public services through e-administration practices, because it not only means a different type of administration but is mainly a different method of communicating with stakeholders (Scholl et al. 2007; Verma and Mishra 2009; Maj 2018a, 2018b). Secondly, it focuses on stakeholder's needs and expectations, with emphasis on their active role in the process of designing and providing the services (Bryson et al. 2007; Florentina 2013; Hawrysz and Maj 2017). Thirdly, thanks to e-administration practices, it becomes more open, whereas mechanisms and ideas from the administration's interorganizational relationships become more absorbed and used more effectively, while environment players act as partners for administrative entities (Bonsón et al. 2012). Fourth, thanks to e-administration practices, the quality, availability, and economic effectiveness of the service provision process improve (Pina et al. 2010). Fifth, the omnipresence of technologies prevents them from being ignored in any dimension of private and occupational life. It is not without significance that such a method of providing public services (through e-administration practices) is relatively new and unexplored (Del Sordo et al. 2017). In this paper, e-administration is understood as the use of Information and communication technologies (ICT) by public sector organizations in relation to organizational change, as well as new abilities to improve the services provided by these organizations.

This paper is organized in the following manner. The next sections include a review of the subject literature, especially of literature concerning the multi-dimensional model of measuring the effects of e-administration and strategic orientation. The review constitutes a basis for the formulation of the research hypothesis. The next section, Section 4 , includes a description of the sample. The empirical results along with a discussion and conclusions are presented in the last sections of this paper.

\section{Multidimensional Model of Measuring Effects of E-Administration}

When analyzing the effects of applying IT systems in the public administration, it is possible to observe the lack of development in the measurement of specific dimensions (Petter et al. 2008). Researchers mainly focused on single dimensions, e.g., on the working environment (Petter et al. 2008; Prybutok et al. 2008), using the following indicators: productivity, efficiency, and task improvement (Adams et al. 1992; Segars and Grover 1993; Gable et al. 2008). Researchers also analyzed e-administration systems from a citizen's point of view (Wang and Liao 2008) and rated the availability and variety of 
online e-administration information and services (Teo et al. 2009; Connolly et al. 2010). In some papers, researchers applied a single-dimension measure (Petter and McLean 2009) that does not take into account the complexity of the services' provision process (Marwa and Zairi 2009). Therefore, further studies focused on developing the measures of e-administration effects, especially with an approach that encompasses the multi-dimensional nature of these effects, are required. The e-administration effects' measurement is not well understood among practitioners or scientific communities (Heeks 2008) and the development of success measures (Korneta 2019) is an urgent task that would allow for technology investments justifying their public value (Yildiz 2007).

Taking into consideration the need to include many dimensions to measure e-administration effects, it is proposed to use the CAF model's part that is widely known (and accepted) in public administration. It takes into consideration three perspectives, i.e., the citizen, society, and employee perspectives.

Most of the changes occurring in e-administration result from the society's and citizens' expectations. However, as subsequent branches of e-services grow, their designers are aware that they often do not know what e-administration citizens want. IT tools providing new methods of delivering information and citizen consulting, but determining citizen and the society's preferences concerning the e-services' structure and contents, is a real challenge for Organisation for Economic Co-operation and Development (OECD) states. Nowadays, we are expecting open, flexible, and collaborative e-administration services, which are needed to empower citizens and the society (Salvati 2017). The call for holistic e-administration recognizes the problem of fragmentation that occurs when citizens and businesses need to negotiate with multiple agencies to receive public services. The level of public service effectiveness usually rises with the level of collaboration and integration (Chen et al. 2019).

This is the reason why increasing public participation, transforming administrative bureaucracies (Cumbie and Kar 2016; Ma and Zheng 2018; Lee-Geiller and Lee 2019), promoting transparency (Bearfield and Bowman 2017), and improving service provision (Zheng 2017) have become very important indicators of e-administration effects. Henceforth, the measurement of the "citizen" perspective features the use of four indicators: identification of ways to improve quality, flexible adaptation to the citizens' changing needs, engaging citizens in the process of designing/redesigning/providing the services, as well as care for the services' transparency.

The development of a society-focused approach requires co-operation. Due to the fact that services are becoming more complex, efficiency requires greater co-operation between agencies in the following fields: cross-boundary collaboration and integration for improving the services' quality, providing the highest quality of services at the lowest possible cost, eliminating unnecessary features, and avoiding duplication of the same initiatives (Lee et al. 2011; Kuk and Janssen 2013; Nograšek and Vintar 2014). Accordingly, the measurement of the "society" perspective featured the use of the following four indicators: coordination of the efforts of different units to improve the quality of services, providing the highest quality of services at the lowest possible cost, elimination of unnecessary formalities, and avoiding repetition of the same initiatives.

The consideration of the employees' role is a complement to the two aforementioned perspectives. Effective e-administration functioning requires broadening employee power to aid citizens in the quickest and most suitable manner by accelerating administrative processes and optimizing governmental solutions. State officials are to effectively collaborate with other departments, rely on the newest information, use the available resources in an optimal manner, and utilize the most adequate support (Rao 2011). These are not simple activities and employees are faced with completely different requirements than in the past. This means that the implementation of the e-administration concept requires the working environment's redesigning. The postulated manner of e-administration functioning requires providing an atmosphere based on openness, trust, friendly relations, and employee engagement in an organization (Dukić et al. 2017; Ejdys 2018; Sagarik et al. 2018).

Accordingly, the measurement of the "employee" perspective featured the use of the following four indicators: care for employee engagement, care for improving relations between employees, care for increased trust among employees, and flexible adaptation to the employees' changing needs. 
The construct is mainly focused on the active inclusion of all interested parties in the organization's management process. The construct takes into consideration the perspective of the entire organization and its principal advantage is the ease of application and the principal disadvantage-subjectivity.

Having a defined construct for analyzing the effects of e-administration, we can deal with the consideration of strategic orientation and the impact of the aforementioned effects.

\section{Strategic Orientation}

Due to the fact that strategic management in public administration is becoming increasingly important in recent years (Poister et al. 2010; Walker 2013), we expected that a search of literature on this topic would provide a lot of papers. Indeed, a Web of Science search of paper titles and abstracts using "strategic" management undertaken in March 2020 identified around 2708 papers in the Public Administration section. However, relatively few examine Miles and Snow as well as performance (Meier et al. 2008, 2010; Andrews et al. 2009a, 2009b, 2011; Boyne and Walker 2010; Walker et al. 2013; Flink 2015; Staples and Dalrymple 2016; Cheon and An 2017; Pasha et al. 2018; Kim and Berry 2018; Lim et al. 2018). The strategic archetypes of prospector, defender, analyzer, and reactor are the best-known aspects of the Miles and Snow framework (Walker 2013). Each strategic orientation leads to a different response to, what the authors specify as, entrepreneurial, engineering, and administrative problems (Sebaa et al. 2009; Wolniak et al. 2019).

Prospectors are organizations that are continuously looking for market opportunities and regularly experiment with potential responses to emerging environmental trends (Miles et al. 1978). In the public sector, prospectors often try to increase budgets and pioneer the development of new products and services (Andrews et al. 2011). The prospectors' preferred strategy processes are based on hunches, intuition, and a reliance on the push and pull of organizational politics (Walker 2013). Prospectors are poised to expand or contract their activities, depending on the opportunities or threats that they face, so the planning cycle is seldom systematic or complete (Andrews et al. 2011). For prospectors, the goal is to be the first to market a new product, with innovation as the key to their success. They are focusing on their efforts on growth and innovation more consistently than other strategic types (Sebaa et al. 2009). The increased public administration effectiveness requires the adoption of criteria applied broadly in the economic (Rokita-Poskart and Mach 2019) network market, i.e., increasing the number of organizations that exchange information electronically using cross-organizational IT systems and connection with supplier, distribution, and customer systems, and the resulting effects of building relations with various stakeholders (Tan et al. 2007; Gatautis et al. 2009; Verma and Mishra 2009; Lips 2013; Maj 2015). The effectiveness of these activities requires thorough redesigning, starting with the workplace, throughout the organization and ending at the organizational level (Kassen 2014). The core of strategy orientation of prospectors is active market monitoring, i.e., in the case of e-administration of the changing needs of stakeholders, and then adapting to them. We therefore propose that:

Hypothesis 1 (H1). A prospector orientation is positively related to the effects of e-administration.

Defenders are organizations that look at the development of new products in a conservative manner. They usually compete on price and quality rather than new products or markets and are focusing on improving the efficiency of their existing operations. Public sector defenders are likely to focus on low-risk strategies designed to increase the efficiency of their existing services (Andrews et al. 2011). Defenders adopt a centralized structure to maintain control over efficient services that focus on core business or service goals. Defenders undertake a lot of formal planning, collect and analyze large amounts of data on service needs, evaluate options to meet those needs, and use advanced techniques to balance the costs and benefits of each option (Walker 2013). Defenders plan intensely and in detail and carefully evaluate any proposed changes in technology and procedures before taking action (Andrews et al. 2011). Defender organizations usually direct their products or services to a clearly 
defined market and emphasize a stable set of products and customers. They constantly strive to update their current technology to maintain efficiency. Innovative change, growth, and diversification are achieved incrementally through market penetration (Sebaa et al. 2009). Due to the specifics of e-government functioning, settling on clearly defined internal structure and processes, as well as formal planning, collecting, analyzing, and evaluating large amounts of data on service needs, it seems to us that a defender orientation is positively related to the effects of e-administration:

Hypothesis 2 (H2). A defender orientation is positively related to the effects of e-administration.

Analyzers constitute a midway category between prospector and defender. Analyzers adopt intermediate structures and processes that depend on the emphasis on proactive or conservative strategy (Walker 2013). Due to the interest in e-administration, which has to deal with the complexity of the services' provision process (Marwa and Zairi 2009) and with the conflicting and competing goals (Pollitt and Bouckaert 2004; Kickert 2007), it is unlikely that this "composite mix" strategic type would be positively related to performance. Analyzers exhibit characteristics of both Defenders and Prospectors in that they are opportunistic in widening their spectrum and reach by quickly following in the footsteps of first movers while also relying on a strong position in a few essential product/service categories or among a firm core of customers. In a strictly ordered world of public money, opportunism is not a safe orientation, and therefore desirable and effective.

Hypothesis 3 (H3). An analyzer orientation is not positively related to the effects of $e$-administration.

Reactors are characterized by an absence of strategy, including inconsistent structures and processes. Reactors in the public sector do not have their own strategy but are waiting for an impulse or coercion of external forces, such as regulator interventions (Andrews et al. 2011). Reactor organizations do not take the lead, they rather react to market pressures and demands. They do not seek to innovate or to be the first-to-market and have little involvement in research and development (Sebaa et al. 2009). Reactors do not have a set of mechanisms that allow them to react consistently to the environment (Miles et al. 1978). However, if we consider the openness that e-administration should demonstrate in its interaction with stakeholders, the reactor orientation may be positively related to effects. We therefore propose that:

Hypothesis $4 \mathbf{( H 4 ) . ~ A ~ r e a c t o r ~ o r i e n t a t i o n ~ i s ~ p o s i t i v e l y ~ r e l a t e d ~ t o ~ t h e ~ e f f e c t s ~ o f ~ e - a d m i n i s t r a t i o n . ~}$

\section{Materials and Methods}

The proper study was focused on public entities that provide electronic administrative services. The research sample was established based on the Act of 24 July 1998, which introduced the three-level territorial division of the state. According to the act, the units of the primary three-level territorial division in Poland include municipalities, powiats, and voivodeships. According to the data available as of 30 September 2017, Poland features 2803 entities that mostly employ less than 9 people. However, the study only featured organizations that hired more than 10 employees. This method of narrowing the population was aimed at identifying the capabilities that are intentionally embedded in the processes and have no effect of spontaneous multi-directional interaction taking place in micro-organizations. In such organizations, the problem of loss of conveyed information (especially along hierarchic levels) does not occur in principle, therefore the organizations do not have to develop the management notification mechanisms and procedures (Wolniak et al. 2019). After such narrowing, the study sample featured 634 entities. The request for taking part in the study was sent via a cover letter to persons holding the highest positions in each of these organizations. Two hundred and eighty-eight organizations out of a sample of 634 entities took part in the study. With a fraction of 0.5 and maximum error of $5 \%$, the obtained study sample meets the minimum sample condition. Due to the lack of responses or their inconsistency, the sample ultimately featured 226 public administration organizations. 
The data collection was conducted with the use of the Computer-Assisted Web Interview (CAWI), in the period from November 2017 to January 2018.

All scales for measuring particular constructs are seven-point Likert scales, from 1-“I strongly disagree" to 7-“I completely agree". The survey questionnaire consisted of twenty-four questions. Twelve questions concerned three dimensions-citizen, society, and employee (four questions for each dimension) - described in detail in the multi-dimensional model of measuring effects of e-administration. Twelve questions concerned strategic orientation-prospector, defender, analyzer, and reactor (three questions for each orientation).

The paper was mainly focused on providing public services through electronic administration practices in Poland, because due to its social and economic situation prior to 1990, Poland has for many years been behind other European states in terms of implementing the e-administration concept. Admittedly, the first talks about e-administration in Poland commenced after the presentation of the European Committee's report of 1994, but specific action towards building the bases of an information society in Poland were taken in 2000. However, the action featured a lack of coordination of the executed projects (Bebenek 2016) and the projects themselves were treated only as technological changes, which contributed to widening the gap between Poland and other EU states. The report on state management processes' computerization published by the UN in 2012 demonstrated that Poland was in the forty-seventh spot, whereas in 2010, it ranked forty-fifth, and in 2008 - thirty-third, even despite the enormous EU resources contributed to the related investments. Poland was ranked behind Kazakhstan, Croatia, or Russia, the starting situations of which were difficult. Secondly, for many years Poland lacked a complex, multi-dimensional, and far-reaching approach. It was decided to implement numerous discipline-specific solutions applicable to particular fields of public administration activity, which functioned in isolation from systems that required co-operation. This solution responded to the need of particular public administration sectors; however, it did not ensure the sufficient interoperability of the systems. Providing services as part of e-administration requires establishing multi-directional co-operation of units regulated by separate legal acts and possessing systems that are incompatible and unable to establish mutual communication. The aforementioned factors and other, not mentioned in the paper, lead to rapid transformations in the Polish e-administration in recent years, which makes e-administration a very interesting and relatively unexplored research field.

\section{Results}

To achieve the objective of this study, which is assessing the influence of strategic orientation and effects of e-administration, therefore, the method of Ordinary Least Squares (OLS) was used, as it is the most popular method used in estimating the parameters of the multiple regression models and normally fit for explaining cross-sectional data as in this research. Gujarati asserted that the estimators of OLS are exclusively specified based on observable $(X, Y)$ quantities which could be simply calculated (Gujarati 2004). Studies have used OLS regression (Lee et al. 2001). Therefore, the OLS model that depicts the association between the regress and the regressors is regarded as follows:

$$
Y=\beta_{0}+\beta_{1} X_{1}+\beta_{2} X_{2}+\ldots+\beta_{k} X_{k}+U
$$

The model is linear in its parameters. Empirically, in this study, the model describes strategic orientation and effects of e-administration. Thus, to achieve this objective, the model is estimated as

$$
\begin{aligned}
& \text { Citizen } 1=\beta_{0}+\beta_{1} \text { Prospector }+\beta_{2} \text { Defender }+\beta_{3} \text { Analyzer }+\beta_{4} \text { Reactor }+\mathrm{u} \\
& \text { Citizen } 2=\beta_{0}+\beta_{1} \text { Prospector }+\beta_{2} \text { Defender }+\beta_{3} \text { Analyzer }+\beta_{4} \text { Reactor }+\mathrm{u} \\
& \text { Citizen } 3=\beta_{0}+\beta_{1} \text { Prospector }+\beta_{2} \text { Defender }+\beta_{3} \text { Analyzer }+\beta_{4} \text { Reactor }+\mathrm{u} \\
& \text { Citizen } 4=\beta_{0}+\beta_{1} \text { Prospector }+\beta_{2} \text { Defender }+\beta_{3} \text { Analyzer }+\beta_{4} \text { Reactor }+\mathrm{u}
\end{aligned}
$$


where Citizen 1 represents the identification of ways to improve quality; Citizen 2 represents the flexible adaptation to the changing needs of citizens; Citizen 3 represents engaging citizens in the process of designing/redesigning/providing services; Citizen 4 represents care for the transparency of services provided. $\beta_{0}, \beta_{1}, \beta_{2}, \beta_{3}, \beta_{4}$ are the parameters to be estimated while $u$ is the error term, and $u$ has a normal distribution with the expected value of 0 and variance of $\sigma^{2}$.

$$
\begin{aligned}
& \text { Society } 1=\beta_{0}+\beta_{1} \text { Prospector }+\beta_{2} \text { Defender }+\beta_{3} \text { Analyzer }+\beta_{4} \text { Reactor }+\mathrm{u} \\
& \text { Society } 2=\beta_{0}+\beta_{1} \text { Prospector }+\beta_{2} \text { Defender }+\beta_{3} \text { Analyzer }+\beta_{4} \text { Reactor }+\mathrm{u} \\
& \text { Society } 3=\beta_{0}+\beta_{1} \text { Prospector }+\beta_{2} \text { Defender }+\beta_{3} \text { Analyzer }+\beta_{4} \text { Reactor }+\mathrm{u} \\
& \text { Society } 4=\beta_{0}+\beta_{1} \text { Prospector }+\beta_{2} \text { Defender }+\beta_{3} \text { Analyzer }+\beta_{4} \text { Reactor }+\mathrm{u}
\end{aligned}
$$

where Society 1 represents coordinating the efforts of different units to improve the quality of services; Society 2 represents providing the highest quality services at the lowest possible costs; Society 3 represents the elimination of unnecessary formalities; Society 4 represents avoiding repetition of the same initiatives. $\beta_{0}, \beta_{1}, \beta_{2}, \beta_{3}, \beta_{4}$ are the parameters to be estimated while $u$ is the error term, and $u$ has a normal distribution with the expected value of 0 and variance of $\sigma^{2}$.

$$
\begin{aligned}
& \text { Employee } 1=\beta_{0}+\beta_{1} \text { Prospector }+\beta_{2} \text { Defender }+\beta_{3} \text { Analyzer }+\beta_{4} \text { Reactor }+\mathrm{u} \\
& \text { Employee } 2=\beta_{0}+\beta_{1} \text { Prospector }+\beta_{2} \text { Defender }+\beta_{3} \text { Analyzer }+\beta_{4} \text { Reactor }+\mathrm{u} \\
& \text { Employee } 3=\beta_{0}+\beta_{1} \text { Prospector }+\beta_{2} \text { Defender }+\beta_{3} \text { Analyzer }+\beta_{4} \text { Reactor }+\mathrm{u} \\
& \text { Employee } 4=\beta_{0}+\beta_{1} \text { Prospector }+\beta_{2} \text { Defender }+\beta_{3} \text { Analyzer }+\beta_{4} \text { Reactor }+\mathrm{u}
\end{aligned}
$$

where Employee 1 represents the care for employee engagement; Employee 2 represents the care for improving relations between employees; Employee 3 represents the care for increased trust among employees; Employee 4 represents the flexible adaptation to the changing needs of employees. $\beta_{0}, \beta_{1}$, $\beta_{2}, \beta_{3}, \beta_{4}$ are the parameters to be estimated while $u$ is the error term, and $u$ has a normal distribution with the expected value of 0 and variance of $\sigma^{2}$.

The result of the regression in Table 1 depicts that the value of the R-squared for "Citizen 1" was $55.35 \%$, which implied that approximately $55 \%$ of the changes in Citizen 1 were caused by the independent variable, while the remaining $45 \%$ of the changes were due to other variables not specified in Model 1. The result of the regression shows that Prospector on the effects of e-administration is (coefficient $=0.556150, p<0.0001$ ), and Defender on the effects of e-administration model show (coefficient $=0.351803, p=0.0005$ ). Variables Analyzer and Reactor have been removed from the model with the Student $t$ test.

In the linear regression model, if the value of the explanatory variable (Citizen 1 ) changes by one unit, the expected value of the explained variable (Prospector) will change by the value of the coefficient (0.556150). If the value of the explanatory variable (Citizen 1 ) changes by one unit, the expected value of the explained variable (Defender) will change by the value of the coefficient $(0.351803)$ ceteris paribus.

The result of the regression in Table 2 depicts that the value of the R-squared for "Citizen 2" was $62.36 \%$, which implied that approximately $62 \%$ of the changes in Citizen 2 were caused by the independent variable, while the remaining $38 \%$ of the changes were due to other variables not specified in Model 2. The result of the regression shows that Defender on the effects of e-administration is (coefficient $=0.785115, p<0.0001$ ) and Reactor on the effects of e-administration model show (coefficient $=0.143048, p=0.0326$ ). The regression result of Analyzer depicts (coefficient $=-0.152602, p=0.0103$ ) having a negative value. The variable Prospector has been removed from the model with the Student $t$ test. 
Table 1. Model 1: Ordinary Least Squares (OLS), using observations 1-228. Dependent variable: Citizen 1.

\begin{tabular}{|c|c|c|c|c|c|}
\hline & Coefficient & Std. Error & $t$-Ratio & $p$-Value & \\
\hline Constant & 0.307856 & 0.313845 & 0.9809 & 0.3277 & \\
\hline Prospector & 0.556150 & 0.0883406 & 6.296 & $<0.0001$ & $* * *$ \\
\hline Defender & 0.351803 & 0.0992614 & 3.544 & 0.0005 & $* * *$ \\
\hline Mean dependent variable & \multicolumn{2}{|c|}{5.105263} & S.D. dependent variable & \multicolumn{2}{|l|}{1.261901} \\
\hline Sum squared residual & \multicolumn{2}{|c|}{161.4147} & S.E. of regression & \multicolumn{2}{|l|}{0.846994} \\
\hline R-squared & \multicolumn{2}{|c|}{0.553454} & Adjusted R-squared & \multicolumn{2}{|l|}{0.549484} \\
\hline$F(2,225)$ & \multicolumn{2}{|c|}{139.4336} & $p$-value $(\mathrm{F})$ & \multicolumn{2}{|l|}{$4.07 \times 10^{-40}$} \\
\hline Log-likelihood & \multicolumn{2}{|c|}{-284.1459} & Akaike criterion & \multicolumn{2}{|l|}{574.2919} \\
\hline Schwarz criterion & \multicolumn{2}{|c|}{584.5799} & Hannan-Quinn & \multicolumn{2}{|l|}{578.4428} \\
\hline & $\begin{array}{c}0.307856 \\
(0.313845)\end{array}$ & $\begin{array}{c}0.556150 \\
(0.0883406)\end{array}$ & $*$ Prospector $+\begin{array}{c}0.351803 \\
(0.0992614)\end{array}$ & nder. & \\
\hline
\end{tabular}

In the linear regression model, if the value of the explanatory variable (Citizen 2) changes by one unit, the expected value of the explained variable (Defender) will change by the value of the coefficient (0.785115). If the value of the explanatory variable (Citizen 2) changes by one unit, the expected value of the explained variable (Reactor) will change by the value of the coefficient (0.143048). If the value of the explanatory variable (Citizen 2 ) changes by one unit, the expected value of the explained variable (Analyzer) will change by the value of the coefficient (-0.152602) ceteris paribus.

Table 2. Model 2: OLS, using observations 1-228. Dependent variable: Citizen 2.

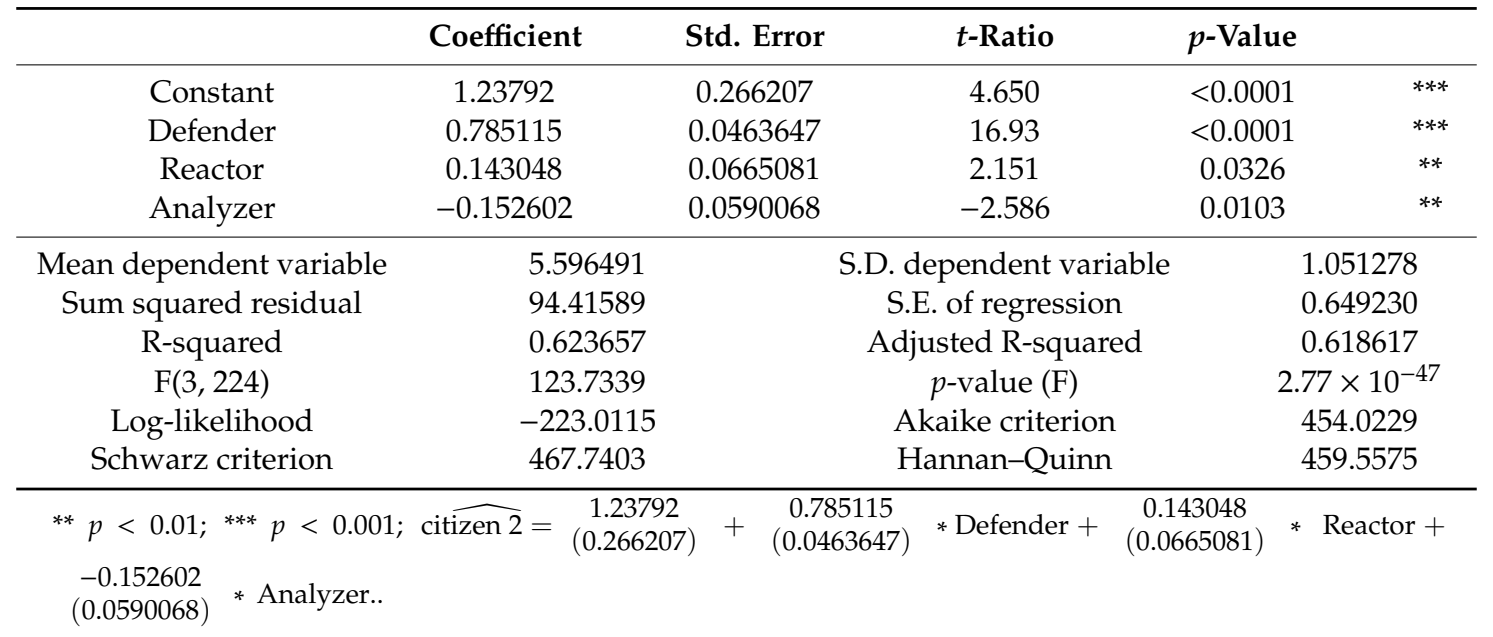

The result of the regression in Table 3 depicts that the value of the R-squared for "Citizen 3" was $71.01 \%$, which implied that approximately $71 \%$ of the changes in Citizen 3 were caused by the independent variable, while the remaining $29 \%$ of the changes were due to other variables not specified in Model 3. The result of the regression shows that Defender on the effects of e-administration is (coefficient $=0.658995, p<0.0001$ ), Reactor on the effects of e-administration model show (coefficient $=0.163939, p=0.0043$ ), and Prospector on the effects of e-administration is (coefficient $=0.148437, p=0.0111$ ). The regression result of Analyzer depicts (coefficient $=-0.179726$, $p=0.0005$ ) having a negative value.

In the linear regression model, if the value of the explanatory variable (Citizen 3) changes by one unit, the expected value of the explained variable (Defender) will change by the value of the coefficient (0.658995). If the value of the explanatory variable (Citizen 3) changes by one unit, the expected value of the explained variable (Reactor) will change by the value of the coefficient (0.163939). If the value of the explanatory variable (Citizen 3 ) changes by one unit, the expected value of the explained variable (Analyzer) will change by the value of the coefficient $(-0.179726)$. If the value of the explanatory 
variable (Citizen 3) changes by one unit, the expected value of the explained variable (Prospector) will change by the value of the coefficient (0.148437) ceteris paribus.

Table 3. Model 3: OLS, using observations 1-228. Dependent variable: Citizen 3.

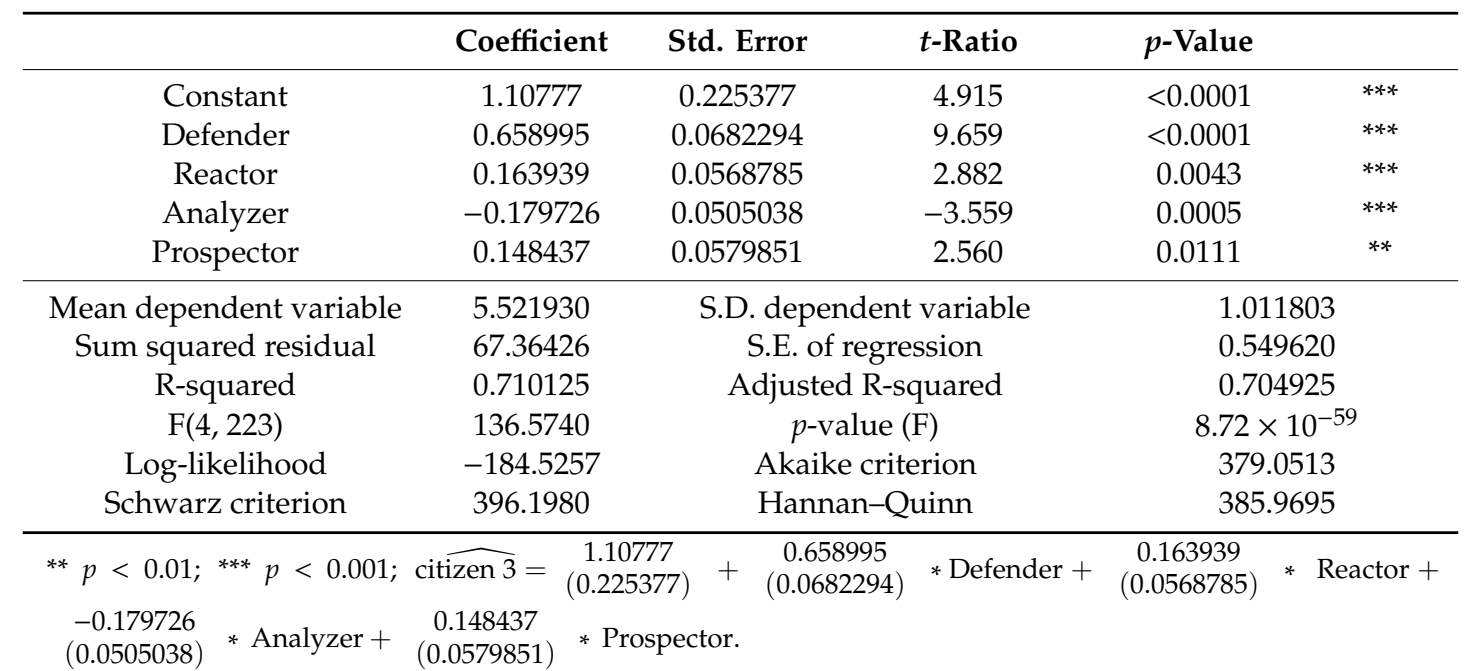

The result of the regression in Table 4 depicts that the value of the R-squared for "Citizen 4 " was $68.59 \%$, which implied that approximately $68 \%$ of the changes in Citizen 4 were caused by the independent variable, while the remaining $32 \%$ of the changes were due to other variables not specified in Model 4. The result of the regression shows that Defender on the effects of e-administration is (coefficient $=0.598966, p<0.0001$ ), and Prospector on the effects of e-administration model show (coefficient $=0.177482, p=0.0014$ ). Variables Analyzer and Reactor have been removed from the model with the Student $\mathrm{t}$ test.

In the linear regression model, if the value of the explanatory variable (Citizen 4) changes by one unit, the expected value of the explained variable (Defender) will change by the value of the coefficient (0.598966). If the value of the explanatory variable (Citizen 4) changes by one unit, the expected value of the explained variable (Prospector) will change by the value of the coefficient $(0.177482)$ ceteris paribus.

Table 4. Model 4: OLS, using observations 1-228. Dependent variable: Citizen 4.

\begin{tabular}{|c|c|c|c|c|c|}
\hline & Coefficient & Std. Error & $t$-Ratio & $p$-Value & \\
\hline Constant & 1.10733 & 0.194827 & 5.684 & $<0.0001$ & $* * *$ \\
\hline Defender & 0.598966 & 0.0616190 & 9.720 & $<0.0001$ & $* * *$ \\
\hline Prospector & 0.177482 & 0.0548396 & 3.236 & 0.0014 & $* * *$ \\
\hline Mean dependent variable & 5.317982 & \multicolumn{2}{|c|}{ S.D. dependent variable } & \multicolumn{2}{|c|}{0.934110} \\
\hline Sum squared residual & 62.20304 & \multicolumn{2}{|c|}{ S.E. of regression } & \multicolumn{2}{|c|}{0.525793} \\
\hline R-squared & 0.685956 & \multicolumn{2}{|c|}{ Adjusted R-squared } & \multicolumn{2}{|c|}{0.683165} \\
\hline $\mathrm{F}(2,225)$ & 245.7304 & \multicolumn{2}{|c|}{$p$-value $(\mathrm{F})$} & \multicolumn{2}{|c|}{$2.58 \times 10^{-57}$} \\
\hline Log-likelihood & -175.4386 & \multicolumn{2}{|c|}{ Akaike criterion } & \multicolumn{2}{|c|}{356.8772} \\
\hline Schwarz criterion & 367.1653 & \multicolumn{2}{|c|}{ Hannan-Quinn } & \multicolumn{2}{|c|}{361.0281} \\
\hline
\end{tabular}

The result of the regression in Table 5 depicts that the value of the R-squared for "Society 1 " was $46.10 \%$, which implied that approximately $46 \%$ of the changes in Society 1 were caused by the independent variable, while the remaining $54 \%$ of the changes were due to other variables not specified in Model 5. The result of the regression shows that Defender on the effects of e-administration is (coefficient $=0.885564, p<0.0001$ ). Variables Prospector, Analyzer, and Reactor have been removed from the model with the Student $t$ test. 
In the linear regression model, if the value of the explanatory variable (Society 1) changes by one unit, the expected value of the explained variable (Defender) will change by the value of the coefficient (0.885564) ceteris paribus.

Table 5. Model 5: OLS, using observations 1-228. Dependent variable: Society 1.

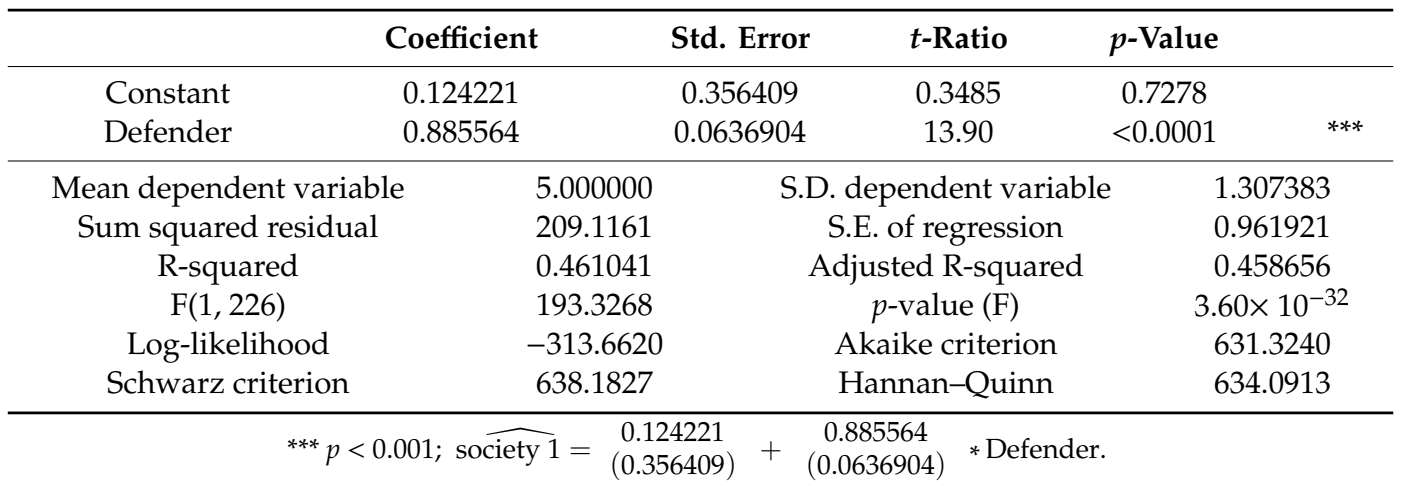

The result of the regression in Table 6 depicts that the value of the R-squared for "Society 2" was $42.21 \%$, which implied that approximately $42 \%$ of the changes in Society 2 were caused by the independent variable, while the remaining $58 \%$ of the changes were due to other variables not specified in Model 6. The result of the regression shows that Defender on the effects of e-administration is (coefficient $=0.842053, p<0.0001$ ) and Analyzer on the effects of e-administration model show (coefficient $=0.0848740, p=0.0800$ ). Variables Prospector and Reactor have been removed from the model with the Student $t$ test.

In the linear regression model, if the value of the explanatory variable (Society 2 ) changes by one unit, the expected value of the explained variable (Defender) will change by the value of the coefficient (0.842053). If the value of the explanatory variable (Society 2 ) changes by one unit, the expected value of the explained variable (Analyzer) will change by the value of the coefficient $(0.0848740)$ ceteris paribus.

Table 6. Model 6: OLS, using observations 1-228. Dependent variable: Society 2.

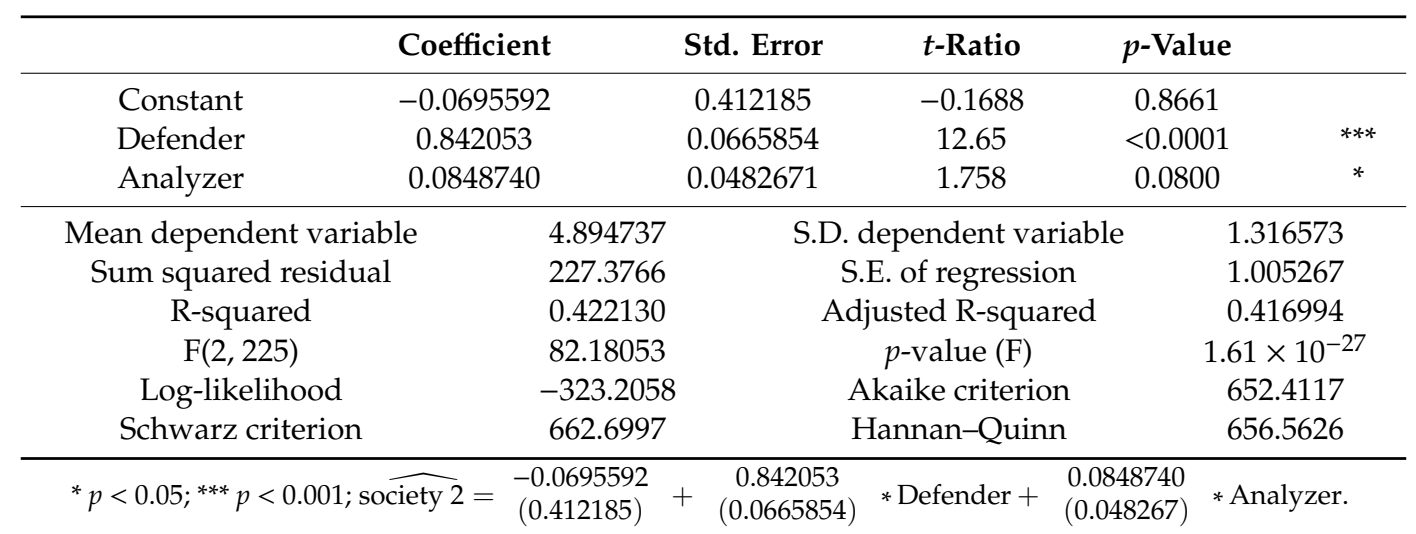

The result of the regression in Table 7 depicts that the value of the R-squared for "Society 3" was $47.04 \%$, which implied that approximately $47 \%$ of the changes in Society 3 were caused by the independent variable, while the remaining $53 \%$ of the changes were due to other variables not specified in Model 7. The result of the regression shows that Defender on the effects of e-administration is (coefficient $=0.803616, p<0.0001$ ) and Reactor on the effects of e-administration model show (coefficient $=0.110531, p=0.0248$ ). Variables Prospector and Analyzer have been removed from the model with the Student $t$ test.

In the linear regression model, if the value of the explanatory variable (Society 3 ) changes by one unit, the expected value of the explained variable (Defender) will change by the value of the coefficient 
(0.803616). If the value of the explanatory variable (Society 3 ) changes by one unit, the expected value of the explained variable (Reactor) will change by the value of the coefficient $(0.110531)$ ceteris paribus.

Table 7. Model 7: OLS, using observations 1-228. Dependent variable: Society 3.

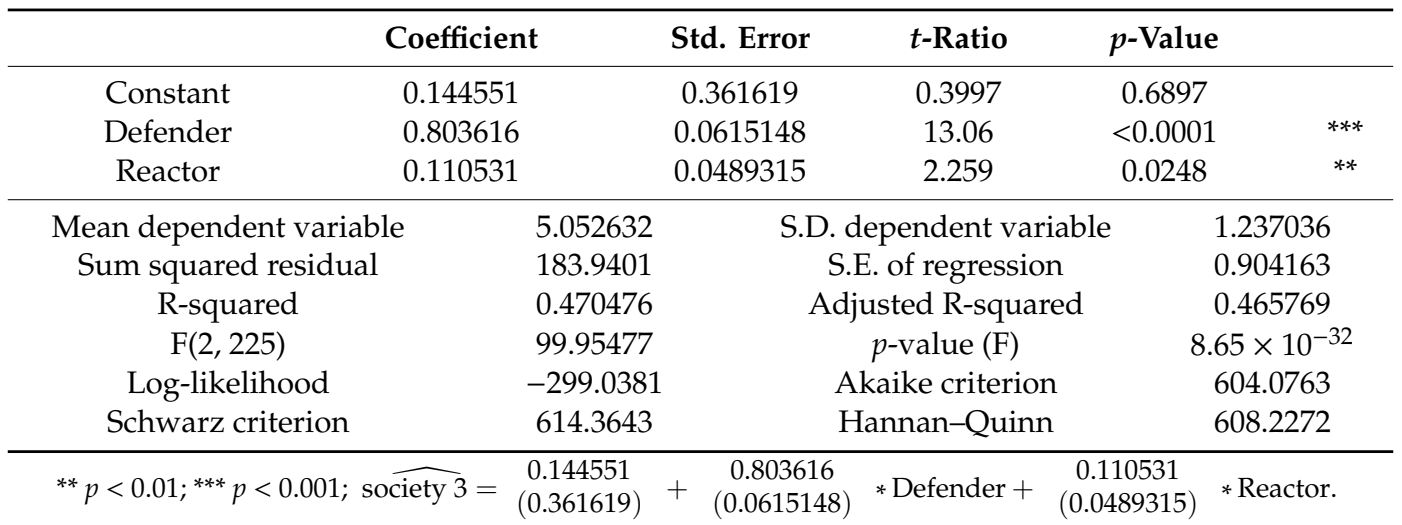

The result of the regression in Table 8 depicts that the value of the R-squared for "Society 4 " was $41.52 \%$, which implied that approximately $41 \%$ of the changes in Society 4 were caused by the independent variable, while the remaining $59 \%$ of the changes were due to other variables not specified in Model 8. The result of the regression shows that Defender on the effects of e-administration is (coefficient $=0.776268, p<0.0001$ ). Variables Prospector, Reactor, and Analyzer have been removed from the model with the Student $t$ test.

In the linear regression model, if the value of the explanatory variable (Society 4 ) changes by one unit, the expected value of the explained variable (Defender) will change by the value of the coefficient (0.776268). If the value of the explanatory variable (Society 4) changes by one unit, the expected value of the explained variable (Analyzer) will change by the value of the coefficient $(0.0543611)$ ceteris paribus.

Table 8. Model 8: OLS, using observations 1-228. Dependent variable: Society 4.

\begin{tabular}{|c|c|c|c|c|}
\hline & Coefficient & Std. Error & $t$-Ratio & $p$-Value \\
\hline Constant & 0.612347 & 0.383093 & 1.598 & 0.1114 \\
\hline Defender & 0.776268 & 0.0618859 & 12.54 & $<0.0001$ \\
\hline Analyzer & 0.0543611 & 0.0448605 & 1.212 & 0.2269 \\
\hline Mean dependent variable & 5.096491 & S.D & endent variable & 1.216403 \\
\hline Sum squared residual & 196.4135 & \multicolumn{2}{|c|}{ S.E. of regression } & 0.934317 \\
\hline R-squared & 0.415222 & \multicolumn{2}{|c|}{ Adjusted R-squared } & 0.410024 \\
\hline $\mathrm{F}(2,225)$ & 79.88083 & \multicolumn{2}{|c|}{$p$-value $(\mathrm{F})$} & $6.12 \times 10^{-27}$ \\
\hline Log-likelihood & -306.5179 & \multicolumn{2}{|c|}{ Akaike criterion } & 619.0358 \\
\hline Schwarz criterion & 629.3238 & \multicolumn{2}{|c|}{ Hannan-Quinn } & 623.1867 \\
\hline
\end{tabular}

The result of the regression in Table 9 depicts that the value of the R-squared for "Employee 1" was $69.42 \%$, which implied that approximately $69 \%$ of the changes in Employee 1 were caused by the independent variable, while the remaining $31 \%$ of the changes were due to other variables not specified in Model 9. The result of the regression shows that Defender on the effects of e-administration is (coefficient $=0.575955, p<0.0001$ ), Reactor on the effects of e-administration model show (coefficient $=0.348458, p<0.0001$ ), and Prospector on the effects of e-administration is (coefficient $=0.182334, p=0.0034$ ). The regression result of Analyzer depicts (coefficient $=-0.240453$, $p<0.0001$ ) having a negative value.

In the linear regression model, if the value of the explanatory variable (Employee 1) changes by one unit, the expected value of the explained variable (Defender) will change by the value of the coefficient (0.575955). If the value of the explanatory variable (Employee 1) changes by one unit, 
the expected value of the explained variable (Prospector) will change by the value of the coefficient (0.182334). If the value of the explanatory variable (Employee 1$)$ changes by one unit, the expected value of the explained variable (Reactor) will change by the value of the coefficient (0.348458). If the value of the explanatory variable (Employee 1) changes by one unit, the expected value of the explained variable (Analyzer) will change by the value of the coefficient $(-0.240453)$ ceteris paribus.

Table 9. Model 9: OLS, using observations 1-228. Dependent variable: Employee 1.

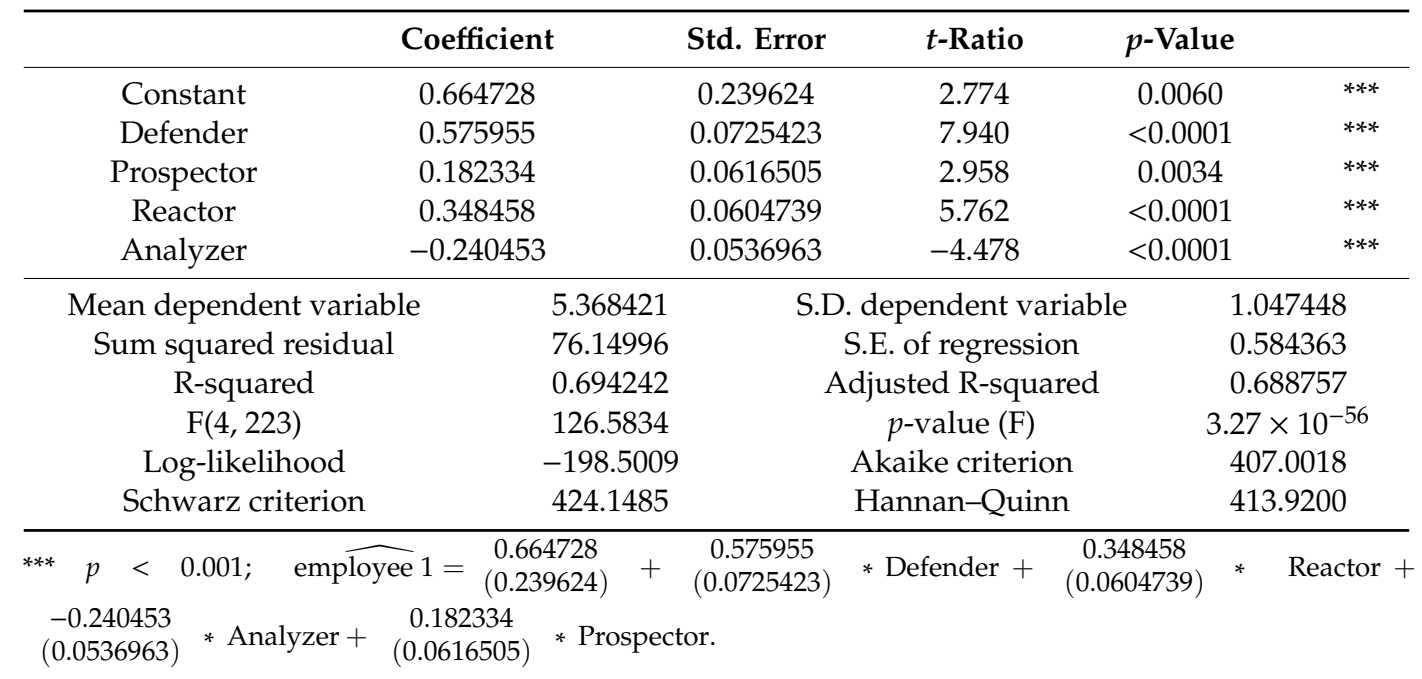

The result of the regression in Table 10 depicts that the value of the R-squared for "Employee 2 " was $66.32 \%$, which implied that approximately $66 \%$ of the changes in Employee 2 were caused by the independent variable, while the remaining $34 \%$ of the changes were due to other variables not specified in Model 10. The result of the regression shows that Defender on the effects of e-administration is (coefficient $=0.594410, p<0.0001$ ), Reactor on the effects of e-administration model show (coefficient $=0.240274, p=0.0002$ ), and Prospector on the effects of e-administration is (coefficient $=0.177097, p=0.0062$ ). The regression result of Analyzer depicts (coefficient $=-0.156714$, $p=0.0054$ ) having a negative value.

In the linear regression model, if the value of the explanatory variable (Employee 2) changes by one unit, the expected value of the explained variable (Defender) will change by the value of the coefficient (0.594410). If the value of the explanatory variable (Employee 2) changes by one unit, the expected value of the explained variable (Prospector) will change by the value of the coefficient (0.177097). If the value of the explanatory variable (Employee 2 ) changes by one unit, the expected value of the explained variable (Reactor) will change by the value of the coefficient $(0.240274)$. If the value of the explanatory variable (Employee 2) changes by one unit, the expected value of the explained variable (Analyzer) will change by the value of the coefficient $(-0.156714)$ ceteris paribus.

The result of the regression in Table 11 depicts that the value of the R-squared for "Employee 3 " was $67.38 \%$, which implied that approximately $67 \%$ of the changes in Employee 3 were caused by the independent variable, while the remaining $33 \%$ of the changes were due to other variables not specified in Model 11. The result of the regression shows that Defender on the effects of e-administration is (coefficient $=0.618028, p<0.0001$ ), Reactor on the effects of e-administration model show (coefficient $=0.308120, p<0.0001$ ), and Prospector on the effects of e-administration is (coefficient $=0.157283, p=0.0156$ ). The regression result of Analyzer depicts (coefficient $=-0.246773$, $p<0.0001$ ) having a negative value. 
Table 10. Model 10: OLS, using observations 1-228. Dependent variable: Employee 2.

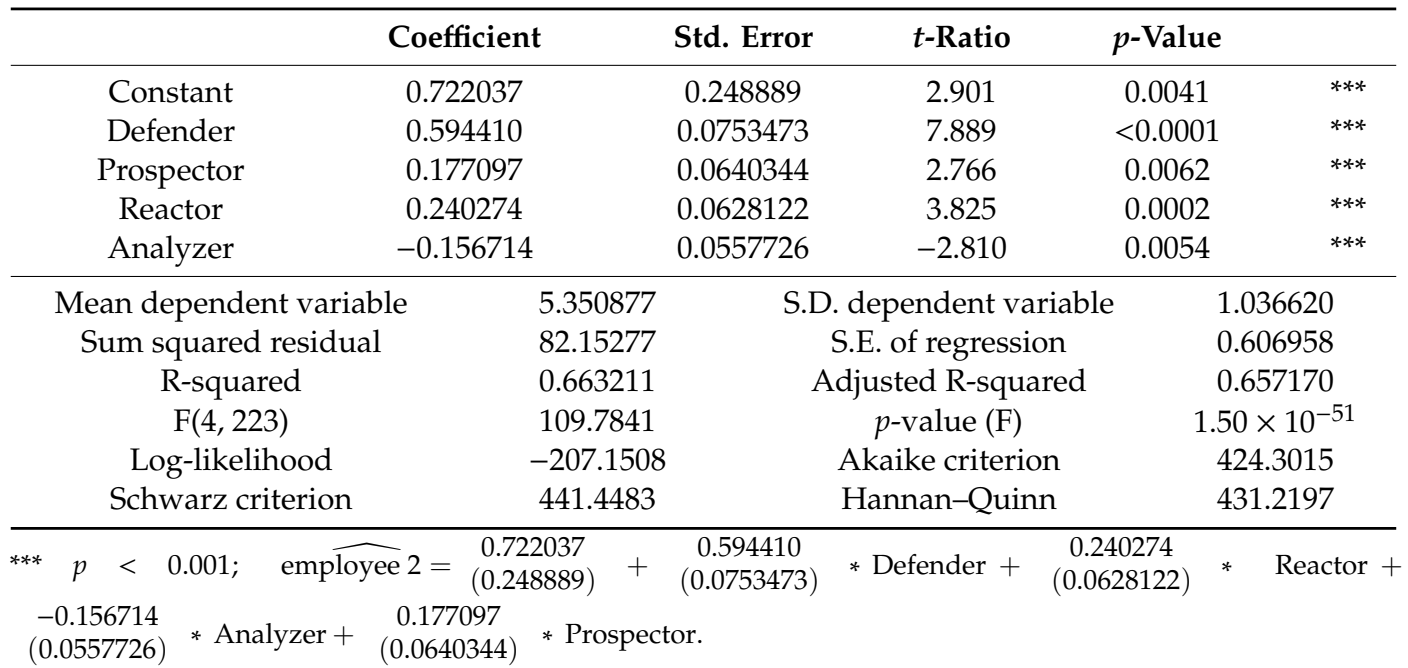

In the linear regression model, if the value of the explanatory variable (Employee 3) changes by one unit, the expected value of the explained variable (Defender) will change by the value of the coefficient (0.618028). If the value of the explanatory variable (Employee 3) changes by one unit, the expected value of the explained variable (Prospector) will change by the value of the coefficient (0.157283). If the value of the explanatory variable (Employee 3 ) changes by one unit, the expected value of the explained variable (Reactor) will change by the value of the coefficient $(0.308120)$. If the value of the explanatory variable (Employee 3 ) changes by one unit, the expected value of the explained variable (Analyzer) will change by the value of the coefficient $(-0.246773)$ ceteris paribus.

Table 11. Model 11: OLS, using observations 1-228. Dependent variable: Employee 3.

\begin{tabular}{|c|c|c|c|c|c|}
\hline & Coefficient & Std. Error & $t$-Ratio & \multicolumn{2}{|l|}{$p$-Value } \\
\hline Constant & 0.824202 & 0.250868 & 3.285 & 0.0012 & $* * *$ \\
\hline Defender & 0.618028 & 0.0759463 & 8.138 & $<0.0001$ & $* * *$ \\
\hline Prospector & 0.157283 & 0.0645434 & 2.437 & 0.0156 & $* *$ \\
\hline Reactor & 0.308120 & 0.0633116 & 4.867 & $<0.0001$ & $* * *$ \\
\hline Analyzer & -0.246773 & 0.0562160 & -4.390 & $<0.0001$ & $* * *$ \\
\hline Mean dependent variable & 5.429825 & \multicolumn{2}{|c|}{ S.D. dependent variable } & \multicolumn{2}{|c|}{1.061703} \\
\hline Sum squared residual & 83.46419 & \multicolumn{2}{|c|}{ S.E. of regression } & \multicolumn{2}{|c|}{0.611783} \\
\hline R-squared & 0.673812 & \multicolumn{2}{|c|}{ Adjusted R-squared } & \multicolumn{2}{|c|}{0.667961} \\
\hline$F(4,223)$ & 115.1635 & \multicolumn{2}{|c|}{$p$-value $(\mathrm{F})$} & \multicolumn{2}{|c|}{$4.30 \times 10^{-53}$} \\
\hline Log-likelihood & -208.9562 & \multicolumn{2}{|c|}{ Akaike criterion } & \multicolumn{2}{|c|}{427.9124} \\
\hline Schwarz criterion & 445.0591 & \multicolumn{2}{|c|}{ Hannan-Quinn } & \multicolumn{2}{|c|}{434.8306} \\
\hline${ }^{* *} p<0.01 ; * * *<0.001 ; \mathrm{em}$ & $=\begin{array}{c}0.824202 \\
(0.250868)\end{array}$ & \multirow[t]{2}{*}{$\begin{array}{c}0.618028 \\
(0.0759463)\end{array}$} & nder + & \multirow[t]{2}{*}{$\begin{array}{c}0.308120 \\
(0.0633116)\end{array}$} & \\
\hline$\frac{-0.246773}{(0.0562160)}$ * Analyzer + & 434) * Prospector & & & & \\
\hline
\end{tabular}

The result of the regression in Table 12 depicts that the value of the R-squared for "Employee 4" was $61.95 \%$, which implied that approximately $62 \%$ of the changes in Employee 4 were caused by the independent variable, while the remaining $38 \%$ of the changes were due to other variables not specified in Model 12. The result of the regression shows that Defender on the effects of e-administration is (coefficient $=0.785628, p<0.0001$ ). Variables Prospector, Analyzer, and Reactor have been removed from the model with the Student $t$ test.

In the linear regression model, if the value of the explanatory variable (Employee 4) changes by one unit, the expected value of the explained variable (Defender) will change by the value of the 
coefficient (0.785628). If the value of the explanatory variable (Employee 4) changes by one unit, the expected value of the explained variable (Reactor) will change by the value of the coefficient (0.0202239) ceteris paribus.

Table 12. Model 12: OLS, using observations 1-228. Dependent variable: Employee 4.

\begin{tabular}{|c|c|c|c|c|c|}
\hline & Coefficient & Std. Error & $t$-Ratio & $p$-Value & \\
\hline Constant & 1.18248 & 0.249905 & 4.732 & $<0.0001$ & $* * *$ \\
\hline Defender & 0.785628 & 0.0425112 & 18.48 & $<0.0001$ & $* * *$ \\
\hline Reactor & 0.0202239 & 0.0338152 & 0.5981 & 0.5504 & \\
\hline Mean dependent variable & 5.596491 & \multicolumn{2}{|c|}{ S.D. dependent variable } & \multicolumn{2}{|c|}{1.008504} \\
\hline Sum squared residual & 87.84626 & \multicolumn{2}{|c|}{ S.E. of regression } & \multicolumn{2}{|c|}{0.624842} \\
\hline R-squared & 0.619511 & \multicolumn{2}{|c|}{ Adjusted R-squared } & \multicolumn{2}{|c|}{0.616129} \\
\hline $\mathrm{F}(2,225)$ & 183.1720 & \multicolumn{2}{|c|}{$p$-value $(\mathrm{F})$} & \multicolumn{2}{|c|}{$6.14 \times 10^{-48}$} \\
\hline Log-likelihood & -214.7896 & \multicolumn{2}{|c|}{ Akaike criterion } & \multicolumn{2}{|c|}{435.5793} \\
\hline Schwarz criterion & 445.8673 & \multicolumn{2}{|c|}{ Hannan-Quinn } & \multicolumn{2}{|c|}{439.7302} \\
\hline
\end{tabular}

The findings provide support for $\mathrm{H} 2$ on the link between Defender orientation and the effects of e-administration. The findings do not provide support for $\mathrm{H} 1, \mathrm{H} 3$, and $\mathrm{H} 4$.

\section{Discussion and Conclusions}

Tables 1-12 present the results of twelve models that are designed to examine the strategic orientation and effects of e-administration. Consistent with our expectations, the Defender stance showed positive effects on the effects of e-administration. The Prospector, Reactor, and Analyzer stances did not show clear supportive effects of e-administration. It is surprising and counterintuitive that the Prospector stance has no positive association with the effects of e-administration, especially with the society perspective. Researchers emphasize that Defender's and Prospector's orientations are closely linked to the environment. A prospecting strategy contributes more to organizational performance when the environment is turbulent, and the organizational structure is relatively decentralized. A defending strategy is especially important for results in more placid environments with organizations that have adopted more centralized structural forms (Walker 2013). This centralization may partly result from the heritage of the centrally planned economy in which Poland and other Central and Eastern European countries have operated for many years.

Prior studies have adopted the strategy typology of Miles and Snow and tested the effects of strategy orientation on public service performance. Researchers generally hypothesize that public organizations with Prospector and Defender stances are positively related to performance, and Reactors have a negative association with performance, though it is pointed out that a Reactor has an advantage under certain circumstances in which responsiveness to stakeholders (e.g., political elites) is required, for instance, in a centralized government system (Boyne and Walker 2010). Miles et al. (1978) argue that centralized organizations provide the most fruitful approach for a Defender, offering tight control over internal operations (Walker 2013). They also argue that Defenders are more rational (Miles et al. 1978). The Defenders' rational formulation and implementation processes are more likely to be successful in organizations that engage in centralized decision-making by providing the top management with a planned and coordinated approach to the development and implementation of strategies (Walker et al. 2010). These findings are consistent with the arguments of Miles and Snow (Miles et al. 1978) on the effectiveness of mechanistic organizations in which power and processes are tightly controlled in pursuit of a fixed strategy of stability and efficiency (Walker 2013). During the designing of the study, it was thought that the specificity of e-administration would make the Prospector stance to be positively associated with the effects of e-administration, but this could not be confirmed. However, there is a broad consensus among researchers about the Prospector stance's 
positive association with organizational performance (Andrews et al. 2006; Andrews et al. 2009a, 2009b; Walker et al. 2010). Our evidence indicates that e-administration may have coherent strategies that fit into the strategy categories of Miles and Snow. However, some researchers criticize strategy research that places organizations in mutually exclusive boxes and assumes that each organization has only a single strategic stance that can be easily observed (Conant et al. 1990). Desarbo et al.'s empirical test of the Miles and Snow model found evidence of hybrid strategic stances within organizations, suggesting that the choice of strategy is messy and complex rather than neat and simple (Desarbo et al. 2005).

Research on the strategic management of public organizations has accelerated over the past two decades. However, it should be remembered that the findings and recommendations for the practice of strategic management come from limited data in only a few geographical locations (Great Britain and the United States) and largely local government settings (Walker 2013). In particular, there is a lack of research on Eastern European countries. The ability to compare our research results with other studies is also limited, because both scales for measurement of strategic types and organizational performance measures used around the world are different. Our research project on strategic types in e-administrations is among the few dealing with this topic that have been carried out in Eastern European countries. Therefore, it is worthwhile to conduct this type of research with larger samples. The findings offered here remain cautionary until more systematic research is undertaken. However, evidence from other sectors points to the veracity of Miles and Snow's arguments, and the growing quantity of e-administration evidence should be extended to provide better practical and theoretical proof.

Funding: This research received no external funding.

Conflicts of Interest: The author declares no conflict of interest.

\section{References}

Adams, Dennis A., R. Ryan Nelson, and Peter A. Todd. 1992. Perceived usefulness, ease of use, and usage of information technology: A replication. MIS Quarterly: Management Information Systems 16: 227-47. [CrossRef]

Andrews, Rhys, George A. Boyne, and Richard M. Walker. 2006. Strategy content and organizational performance: An empirical analysis. Public Administration Review 66: 52-63. [CrossRef]

Andrews, Rhys, George A. Boyne, Jennifer Law, and Richard M. Walker. 2009a. Strategy, structure and process in the public sector: A test of the miles and snow model. Public Administration 87: 732-49. [CrossRef]

Andrews, Rhys, George A. Boyne, Jennifer Law, and Richard M. Walker. 2009b. Strategy formulation, strategy content and performance: An empirical analysis. Public Management Review 11: 1-22. [CrossRef]

Andrews, Rhys, George A. Boyne, Jennifer Law, and Richard M. Walker. 2011. Strategy implementation and public service performance. Administration and Society 43: 643-71. [CrossRef]

Bearfield, Domonic A., and Ann O'M. Bowman. 2017. Can You Find It on the Web? An Assessment of Municipal E-Government Transparency. American Review of Public Administration 47: 172-88. [CrossRef]

Bebenek, P. 2016. The Functioning of Outsourcing in the Polish Farms-Success and Failure in Outsourcing Projects. In 3rd International Multidisciplinary Scientific Conference on Social Sciences and Arts SGEM 2016, Book 2. Albena: Flamingo Grand Congress Center. [CrossRef]

Bonsón, Enrique, Lourdes Torres, Sonia Royo, and Francisco Flores. 2012. Local e-government 2.0: Social media and corporate transparency in municipalities. Government Information Quarterly 29: 123-32. [CrossRef]

Boyne, George A., and Richard M. Walker. 2004. Strategy content and public service organizations. Journal of Public Administration Research and Theory 14: 231-52. [CrossRef]

Boyne, George A., and Richard M. Walker. 2010. Strategic management and public service performance: The way ahead. Public Administration Review 70: s185-s192. [CrossRef]

Bryson, John M., Fran Ackermann, and Colin Eden. 2007. Putting the resource-based view of strategy and distinctive competencies to work in public organizations. Public Administration Review 67: 702-17. [CrossRef]

Chen, Yu-Che, Lung-Teng Hu, Kuan-Chiu Tseng, Wen-Jong Juang, and Chih-Kai Chang. 2019. Cross-boundary e-government systems: Determinants of performance. Government Information Quarterly 36: 449-59. [CrossRef] 
Cheon, Ohbet, and Seung-Ho An. 2017. Blowing in the wind: A study for Granger causality between managerial strategy and organizational performance. Public Management Review 19: 686-704. [CrossRef]

Conant, Jeffrey S., Michael P. Mokwa, and P. Rajan Varadarajan. 1990. Strategic types, distinctive marketing competencies and organizational performance: A multiple measures-based study. Strategic Management Journal 11: 365-83. [CrossRef]

Connolly, Regina, Frank Bannister, and Aideen Kearney. 2010. Government website service quality: A study of the Irish revenue online service. European Journal of Information Systems 19: 649-67. [CrossRef]

Cumbie, Barry A., and Bandana Kar. 2016. A Study of Local Government Website Inclusiveness: The Gap Between E-government Concept and Practice. Information Technology for Development 22: 15-35. [CrossRef]

Del Sordo, Carlotta, Rebecca L. Orelli, and Emanuele Padovani. 2017. Governing the public sector e-performance: The accounting practices in the digital age. In Decision Management: Concepts, Methodologies, Tools, and Applications. Hershey: IGI Global. [CrossRef]

Desarbo, Wayne S., C. Anthony Di Benedetto, Michael Song, and Indrajit Sinha. 2005. Revisiting the miles and snow strategic framework: Uncovering interrelationships between strategic types, capabilities, environmental uncertainty, and firm performance. Strategic Management Journal 26: 47-74. [CrossRef]

Dukić, Darko, Gordana Dukić, and Neven Bertović. 2017. Public administration employees' readiness and acceptance of e-government: Findings from a Croatian survey. Information Development 33: 525-39. [CrossRef]

Ejdys, Joanna. 2018. Building technology trust in ICT application at a university. International Journal of Emerging Markets. [CrossRef]

Flink, Carla M. 2015. Multidimensional Conflict and Organizational Performance. American Review of Public Administration 45: 182-200. [CrossRef]

Florentina, Neamţu. 2013. Stakeholders, the determinant factors in development and operationalization of e-governance in Romania. Annals of the University of Oradea, Economic Science Series 22: 595-604.

Gable, Guy G., Darshana Sedera, and Taizan Chan. 2008. Re-conceptualizing information system success: The IS-impact measurement model. Journal of the Association of Information Systems 9: 18. [CrossRef]

Gatautis, Rimantas, Elena Vitkauskaite, and Genadijus Kulvietis. 2009. Lithuanian eGovernment interoperability model. Engineering Economics 2: 38-48. [CrossRef]

Gujarati, Damodar N. 2004. Basic Econometrics, 4th ed. New Delhi: Tata McGraw Hill. [CrossRef]

Harrow, Jenny. 2000. Public Management Reform: A Comparative Analysis. Long Range Planning 6: 881-84. [CrossRef]

Hawrysz, Liliana, and Jolanta Maj. 2017. Identification of stakeholders of public interest organisations. Sustainability 9: 1609. [CrossRef]

Heeks, Richar. 2008. Benchmarking e-Government: Improving the national and international measurement, evaluation and comparison of e-Government. Evaluating Information Systems: Public and Private Sector 257. [CrossRef]

Kassen, Maxat. 2014. Globalization of e-government: Open government as a global agenda; benefits, limitations and ways forward. Information Development 30: 51-58. [CrossRef]

Kickert, Walter. 2007. The Study of Public Management in Europe and the US, The Study of Public Management in Europe and the US. New York: Routledge. [CrossRef]

Kim, Na Yeon, and Frances S. Berry. 2018. Strategic stances and programme performance: Assessing outcomes of the US states' delivery of the child support enforcement programme. Public Management Review 20: 545-62. [CrossRef]

Korneta, Piotr. 2019. Critical success factors for Polish agricultural distributors. British Food Journal. [CrossRef]

Kuk, George, and Marijn Janssen. 2013. Assembling infrastructures and business models for service design and innovation. Information Systems Journal 23: 445-69. [CrossRef]

Lee, Choonwoo, Kyungmook Lee, and Johannes M. Pennings. 2001. Internal capabilities, external networks, and performance: A study on technology-based ventures. Strategic Management Journal 22: 615-40. [CrossRef]

Lee, Chung-pin, Kaiju Chang, and Frances Stokes Berry. 2011. Testing the Development and Diffusion of E-Government and E-Democracy: A Global Perspective. Public Administration Review 71: 444-54. [CrossRef]

Lee-Geiller, Seulki, and Taejun David Lee. 2019. Using government websites to enhance democratic E-governance: A conceptual model for evaluation. Government Information Quarterly 36: 208-25. [CrossRef]

Lim, Edwin KiaYang, Keryn Chalmers, and Dean Hanlon. 2018. The influence of business strategy on annual report readability. Journal of Accounting and Public Policy 37: 65-81. [CrossRef] 
Lips, Miriam. 2013. E-Government is dead: Long live Public Administration 2.0. ICT, Public Administration and Democracy in the Coming Decade 17: 239-50. [CrossRef]

Ma, Liang, and Yueping Zheng. 2018. Does e-government performance actually boost citizen use? Evidence from European countries. Public Management Review 20: 1513-32. [CrossRef]

Maj, J. 2015. Diversity management's stakeholders and stakeholders management. Paper presented at the 9th International Management Conference, "Management and Innovation for Competitive Advantage", Bucharest, Romania, November 5-6.

Maj, Jolanta. 2018a. Embedding diversity in sustainability reporting. Sustainability 10: 2487. [CrossRef]

Maj, Jolanta. 2018b. Nature of non-financial information disclosed by Polish organisations. Paper presented at the 31st International Business Information Management Association Conference, IBIMA 2018: Innovation Management and Education Excellence through Vision 2020, Milan, Italy, April 25-26.

Marwa, Simmy M., and Mohamed Zairi. 2009. In pursuit of performance-oriented civil service reforms (CSRs): A Kenyan perspective. Measuring Business Excellence 13: 34-43. [CrossRef]

Meier, Kenneth J., Laurence J. O’Toole Jr., George A. Boyne, and Richard M. Walker. 2008. Strategic management and the performance of public organizations: Testing venerable ideas against recent theories. Journal of Public Administration Research and Theory. [CrossRef]

Meier, Kenneth J., Laurence J. O’Toole Jr., George A. Boyne, Richard M. Walker, and Rhys Andrews. 2010. Alignment and results: Testing the interaction effects of strategy, structure, and environment from miles and snow. Administration and Society. [CrossRef]

Miles, Raymond E., Charles C. Snow, Alan D. Meyer, and Henry J. Coleman Jr. 1978. Organizational strategy, structure, and process. Academy of Management Review. [CrossRef]

Nograšek, Janja, and Mirko Vintar. 2014. E-government and organisational transformation of government: Black box revisited? Government Information Quarterly. [CrossRef]

Nograšek, Janja, and Mirko Vintar. 2015. Observing organisational transformation of the public sector in the e-government era. Transforming Government: People, Process and Policy. [CrossRef]

Pasha, Obed Q., Theodore H. Poister, and Lauren H. Edwards. 2018. Mutual Relationship of Strategic Stances and Formulation Methods, and Their Impacts on Performance in Public Local Transit Agencies. Administration and Society. [CrossRef]

Petter, Stacie, and Ephraim R. McLean. 2009. A meta-analytic assessment of the DeLone and McLean IS success model: An examination of IS success at the individual level. Information and Management. [CrossRef]

Petter, Stacie, William DeLone, and Ephraim McLean. 2008. Measuring information systems success: Models, dimensions, measures, and interrelationships. European Journal of Information Systems. [CrossRef]

Pina, Vicente, Lourdes Torres, and Sonia Royo. 2010. Is e-government leading to more accountable and transparent local governments? An overall view. Financial Accountability \& Management. [CrossRef]

Poister, Theodore H., David W. Pitts, and Lauren Hamilton Edwards. 2010. Strategic management research in the public sector: A review, synthesis, and future directions. American Review of Public Administration. [CrossRef]

Pollitt, Christopher, and Geert Bouckaert. 2004. The nature of public management reform. In Public Management Reform: A Comparative Analysis. New York: Oxford University Press.

Prybutok, Victor R., Xiaoni Zhang, and Sherry D. Ryan. 2008. Evaluating leadership, IT quality, and net benefits in an e-government environment. Information and Management. [CrossRef]

Rao, V. 2011. Collaborative Government to Employee (G2E): Issues and Challenges to E-Government. Journal of E-Governance. [CrossRef]

Rokita-Poskart, Diana, and Łukasz Mach. 2019. Selected meso-economic consequences of the changing number of students in academic towns and cities (a case study of Poland). Sustainability 10: 1901. [CrossRef]

Sagarik, Danuvas, Pananda Chansukree, Wonhyuk Cho, and Evan Berman. 2018. E-government 4.0 in Thailand: The role of central agencies. Information Polity. [CrossRef]

Salvati, Eugenio. 2017. E-government and e-democracy in the supranational arena: The enforcing of transparency and democratic legitimacy in the European union. In Digital Media Integration for Participatory Democracy. Hershey: IGI Global. [CrossRef]

Scholl, H. J., R. Fidel, S. Liua, M. Paulsmeyer, and K. Unsworth. 2007. E-Government Field Force Automation: Promises, Challenges, and Stakeholders. In Electronic Government. EGOV 2007. Edited by M. A. Wimmer, J. Scholl and Å Grönlund. Lecture Notes in Computer Science. Berlin and Heidelberg: Springer, vol. 4656. 
Sebaa, Ali Ahmed, James Wallace, and Nelarine Cornelius. 2009. Managerial characteristics, strategy and performance in local government. Measuring Business Excellence. [CrossRef]

Segars, Albert H., and Varun Grover. 1993. Re-examining perceived ease of use and usefulness: A confirmatory factor analysis. MIS Quarterly: Management Information Systems 17: 517-25. [CrossRef]

Staples, Warren, and John Dalrymple. 2016. Construction Procurement and State Government Strategy: Aligned or Disconnected? Australian Journal of Public Administration. [CrossRef]

Tan, Chee-Wee, Shan L. Pan, and Eric T. K. Lim. 2007. Managing Stakeholder Interests in E-Government Implementation: Lessons Learned from a Singapore E-Government Project. International Journal of Electronic Government Research (IJEGR). [CrossRef]

Teo, Thompson S. H., Shirish C. Srivastava, and Li Jiang. 2009. Trust and electronic government success: An empirical study. Journal of Management Information Systems. [CrossRef]

Vakalopoulou, Melpomeni A., George Tsiotras, and Katerina Gotzamani. 2013. Implementing CAF in public administration. Benchmarking: An International Journal. [CrossRef]

Verma, Neeta, and Alka Mishra. 2009. india.gov.in-India's approach in constructing one-stop-solution towards e-Government. ACM International Conference Proceeding Series. [CrossRef]

Walker, Richard M. 2013. Strategic management and performance in public organizations: Findings from the miles and snow framework. Public Administration Review. [CrossRef]

Walker, Richard M., Rhys Andrews, George A. Boyne, Kenneth J. Meier, and Laurence J. O’Toole Jr. 2010. Wakeup call: Strategic management, network alarms, and performance. Public Administration Review. [CrossRef]

Walker, Richard M., George A. Boyne, and Gene A. Brewer. 2013. Public management and performance: Research directions, Public Management and Performance: Research Directions. Cambridge: Cambridge University Press. [CrossRef]

Wang, Yi-Shun, and Yi-Wen Liao. 2008. Assessing eGovernment systems success: A validation of the DeLone and McLean model of information systems success. Government Information Quarterly. [CrossRef]

Wolniak, Radoslaw, Bożena Skotnicka-Zasadzień, and Michał Zasadzień. 2019. Problems of the Functioning of E-Administration in the Silesian Region of Poland from the Perspective of a Person with Disabilities. Transylvanian Review of Administrative Sciences. [CrossRef]

Wronka-Pośpiech, Martyna, and Aldona Frączkiewicz-Wronka. 2016. Strategic Orientation and Organisational Culture in Polish Public Organisations: Insights from the Miles and Snow Typology. Management. [CrossRef]

Yildiz, Mete. 2007. E-government research: Reviewing the literature, limitations, and ways forward. Government Information Quarterly. [CrossRef]

Zheng, Yueping. 2017. Explaining Citizens' E-Participation Usage. Administration E Society. [CrossRef] 